https://doi.org/10.15407/knit2020.04.021

UDC 621.318 .1

A. PH. ILYUSHCHANKA ${ }^{\mathbf{1 , 2}}$, Director General of the State Research and Production Powder Metallurgy Association Director of the State Scientific Institution «Powder Metallurgy Institute named after Academician O. V. Roman»,

Dr. Sci. in Tech., Professor, Corresponding Member of NAS of Belarus

E-mail: Alexil@mail.belpak.by

A. K. KRYVANOS ${ }^{1}$, Deputy Director, PhD in Military Sci.

E-mail: Krivonos_ok@tut.by

S. G. BARAY ${ }^{2}$, Head of the Laboratory of Ceramics, Ph.D. in Tech.

V. V. SAVICH ${ }^{2}$, First Deputy Director, Research Deputy, Ph.D. in Tech., Associate Professor

E-mail: savich@pminstitute.by

${ }^{1}$ State Research and Production Powder Metallurgy Association, Minsk, Belarus

41 Platonova Str., Minsk, 220005 Belarus

${ }^{2}$ State Scientific Institution «O. V. Roman Powder Metallurgy Institute», Minsk, Belarus

41 Platonova Str., Minsk, 220005 Belarus

\title{
MATERIALS AND TECHNOLOGIES OF POWDER METALLURGY IN THE COMPONENTS OF MISSILE AND SPACE ENGINEERING. PROSPECTS OF DEVELOPMENT
}

The use of materials and technologies of powder metallurgy in the components of missile and space engineering is considered. The possibilities of these technologies are shown when producing composite materials, as well as products and coatings thereof through the example of radioabsorbing and radiotransparent materials.

The methods for the synthesis of radioabsorbing materials based on ferrimagnetic materials $\left(\mathrm{NiO}_{0.58} \mathrm{ZnO}_{0.36} \mathrm{Mn}_{0.06} \mathrm{Co}_{0.028} \mathrm{Fe}_{2} \mathrm{O}_{4}-\mathrm{nick}_{-}\right.$ el-zinc ferrites and hexagonal barium ferrite with $\mathrm{W}$-phase $\left(\mathrm{BaCo}_{2} \mathrm{Fe}_{16} \mathrm{O}_{27}\right)$, obtained by MAS and MASHS methods were worked out. Methods of producing high-temperature ceramic radioabsorbing materials using alumina as a dielectric matrix, and a resistive material containing the MAX-phases $\mathrm{Ti}_{2} \mathrm{AlC}$ and $\mathrm{Ti}_{3} \mathrm{AlC}_{2}$ and heat-resistant FeSiTiAl alloy as an electromagnetic pulse absorber were investigated.

The production technique of a ceramic composite radiotransparent material based on high-alumina ceramics in the $\mathrm{Al}_{2} \mathrm{O}_{3}-\mathrm{SiO}_{2}-$ $\mathrm{TiO}_{2}$ system is proposed. The specific technological features of the powder metallurgy method, ensuring the production of materials and products (coatings) for missile-space technology with the required properties, are given.

The promising directions and main tasks for powder metallurgy in the field of producing energy-saturated heterogeneous composite materials are determined.

Keywords: powder metallurgy, missile and space engineering, radioabsorbing and radiotransparent materials, ferrimagnetic materials, high-alumina ceramics.

\section{INTRODUCTION}

Powder metallurgy technologies are one of the main, and in some cases the only way to obtain composite materials with a specific set of properties. Products made from such materials are capable of operating for a long time in various conditions, including those under the influence of space factors. Such materials include [1]:

Цитування: Ilyushchanka A. Ph., Kryvanos A. K., Baray S. G., Savich V. V. Materials and technologies of powder metallurgy in the components of missile and space engineering. Prospects of development. Космічна наука і технологія. 2020. 26, № 4 (125). C. 21-30. https://doi.org/10.15407/knit2020.04.021 
- pseudo-alloys (for example, heavy alloys based on tungsten with additions of nickel, iron or copper, hard alloys based on tungsten or titanium carbides with a cobalt bond);

- antifriction composite materials based on iron or copper with the addition of solid lubricants (for example, graphite, molybdenum and tungsten disulfides, other compounds) and soft metals (lead, tin), other metal compositions that cannot be obtained by traditional technologies;

- powders for applying functional coatings;

- oxide and carbide ceramics, composite materials based on it;

- powder composite materials containing metal and ceramic components;

- intermetallic compounds and much more.

The production of such materials with the required properties is achieved due to the possibility of regulating their structural and phase composition, synthesis of particles of the initial components of the necessary fractions with the required morphology of their surface, which for traditional industrial technologies remains difficult or completely impossible. The selection of powder charge components with the required characteristics, its molding and sintering at certain pressures and temperatures (as a rule, below the melting point of the main component) makes it possible to obtain a material with unique properties [2]. In this case, not only resistance to an aggressive environment is formed, but also a predetermined level of functional properties, which remains during the entire service life of a product made from it.

\section{RESEARCH GOAL}

In a number of designs, modern rocket and space technology has both products and coatings made of radioabsorbing and radio-transparent materials. Products made of radio-absorbing material are used to protect against the effects of electromagnetic radiation, which affects the performance of various technical and biological objects, and to mask them. Radiotransparent materials are widely used in aerodynamic radomes of aircraft and missiles under conditions of aerodynamic and thermal loads and impacts, rain, dust, gas erosion and ionizing radiation, as a partition-window in accelerators and electronic devices to ensure the transmission of electromagnetic radiation [3].
Radio-absorbing and radio-transparent materials are non-metallic materials that ensure absorption or transmission, respectively, of electromagnetic radiation of the radio frequency range $\left(10^{5} \ldots 10^{12} \mathrm{~Hz}\right)$ with minimal reflection. Propagating in the volume of these materials, an electromagnetic pulse creates an alternating electric field, the energy of which for a radio-absorbing material is almost completely converted into thermal or minimally for a radio-transparent one [4].

The Powder Metallurgy Institute (Minsk, Belarus) carries out comprehensive research on the development and manufacture of ceramic radio-absorbing and radio-transparent materials for the microwave frequency range. The main goal of the work is to develop compositions and technological modes for obtaining radio-absorbing and radio-transparent materials, as well as products and coatings made of them by the method of powder metallurgy, having the necessary electrical and thermomechanical characteristics.

\section{RESEARCH RESULTS AND THEIR DISCUSSION}

Ceramic radio-absorbing materials are composite ceramics that absorb electromagnetic radiation due to dielectric and magnetic losses.

Modern radio-absorbing materials are created on the basis of:

- ferrimagnetic compositions that retain their functional properties at temperatures up to $600{ }^{\circ} \mathrm{C}$, which is associated with the violation of their magnetic characteristics in the temperature range exceeding the Curie point [5];

- composite materials consisting of a dielectric matrix alloyed with high-temperature absorber conductors synthesized by various methods [6].

With this in mind, the main directions of research have been formulated, which include:

1. Development of the composition and method of obtaining:

- composite radio-absorbing material based on ferrimagnets;

- materials for use as a high-temperature dielectric matrix;

- composite materials to perform the function of an absorber of electromagnetic waves in a given frequency and temperature range. 

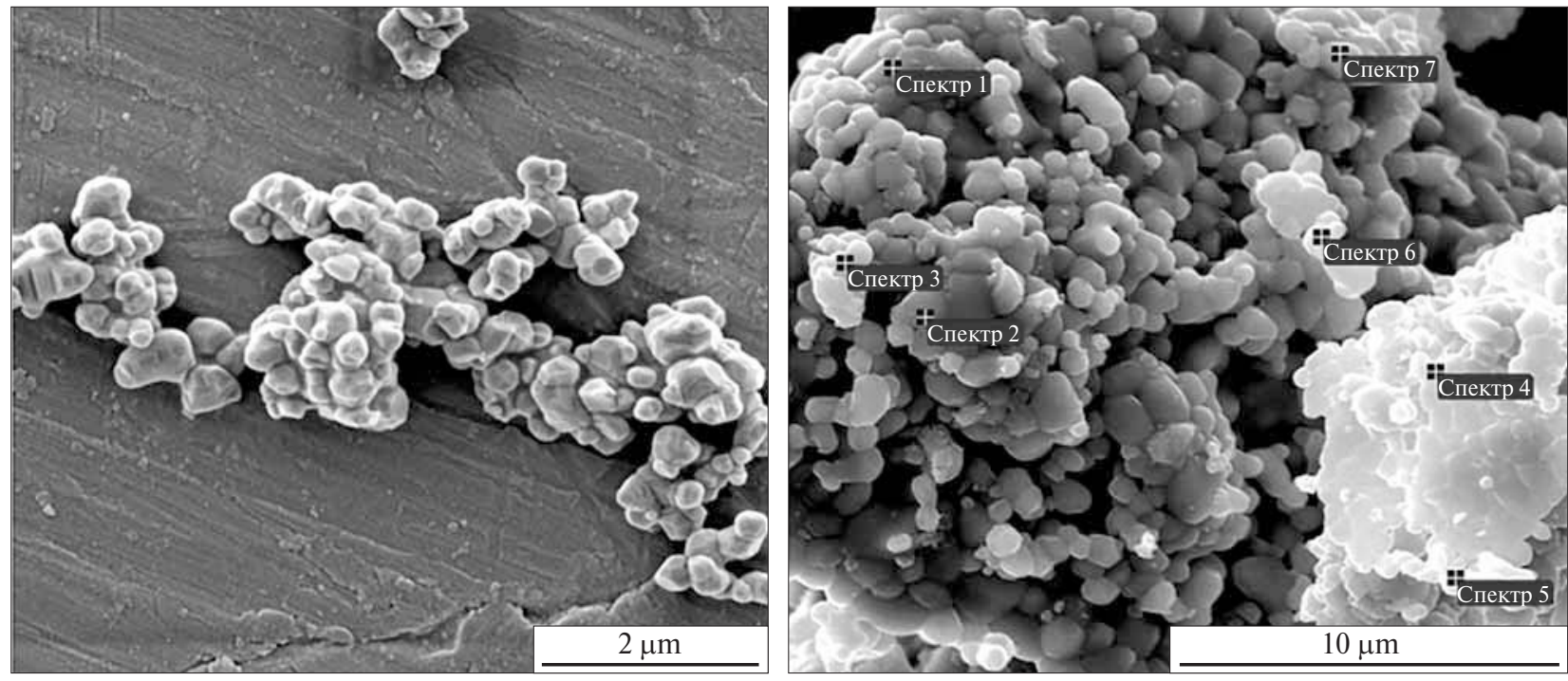

Fig. 1. Surface morphology of nickel-zinc ferrite particles after mechanical activation

\section{Definitions of:}

- a rational ratio of dielectric matrix/absorbing filler to achieve the maximum effect of EMP absorption;

- methods and technological modes of manufacturing products and applying coatings from radioabsorbing materials, etc.

The solution of the above problems was carried out by choosing a production method, within which the composition, concentration and combination of concentrations, shape, particle size, thickness of materials and other parameters were varied. Subsequently, the properties of an article made of a radio-absorbing material were regulated by the modes of pressing the charge and heat treatment of the formed blank. When using a radio-absorbing material as a coating, the properties were regulated by the technological modes of its application to the protected surface.

For the second class of radio-absorbing materials, after the selection of the compositions of the dielectric matrix and the absorber, an appropriate ratio of the matrix/absorbing filler was selected based on the required level of absorption of electromagnetic radiation.

Nanostructured powders of soft magnetic nickelzinc ferrite $\left(\mathrm{NiO}_{0.58} \mathrm{ZnO}_{0.36} \mathrm{Mn}_{0.06} \mathrm{Co}_{0.028} \mathrm{Fe}_{2} \mathrm{O}_{4}\right)$ and magnetically hard hexagonal barium ferrite with the $\mathrm{W}$-phase $\left(\mathrm{BaCo}_{2} \mathrm{Fe}_{16} \mathrm{O}_{27}\right)$ were studied as a composite radio-absorbing material of the first type. To obtain them at the Powder Metallurgy Institute, along with traditional methods, technological modes of mechanically activated synthesis (MAS) and mechanically activated self-propagating high-temperature synthesis (MASHS) have been worked out.

The worked out modes were confirmed during the manufacture of experimental samples of the composite material. So, for nickel-zinc ferrite powder after six hours of mechanical activation, the maximum particle size did not exceed $700 \mathrm{~nm}$, and the minimum was $25 \ldots 30 \mathrm{~nm}$. The morphology of the surface of these particles was filmed using a certified high-resolution scanning electron microscope Mira (manufactured by Tescan, Czech Republic). The results of morphological analysis of nickel-zinc ferrite particles are shown in Fig. 1.

In this case, no chemical interaction between the components of the powder mixture is observed in the process of mechanical activation. To confirm the absence of chemical interaction between the components of the powder charge, its phase composition was studied. The study was carried out on an Ultima IV X-ray diffractometer by Rigaku. The phase composition of mechanically activated powders includes only the initial oxides. The results of the study (phase composition) shown in Fig. 2 confirm the expediency of the selected modes of synthesis of soft magnetic nickel-zinc ferrite, and the obtained sizes of its particles make it possible to achieve the maximum 


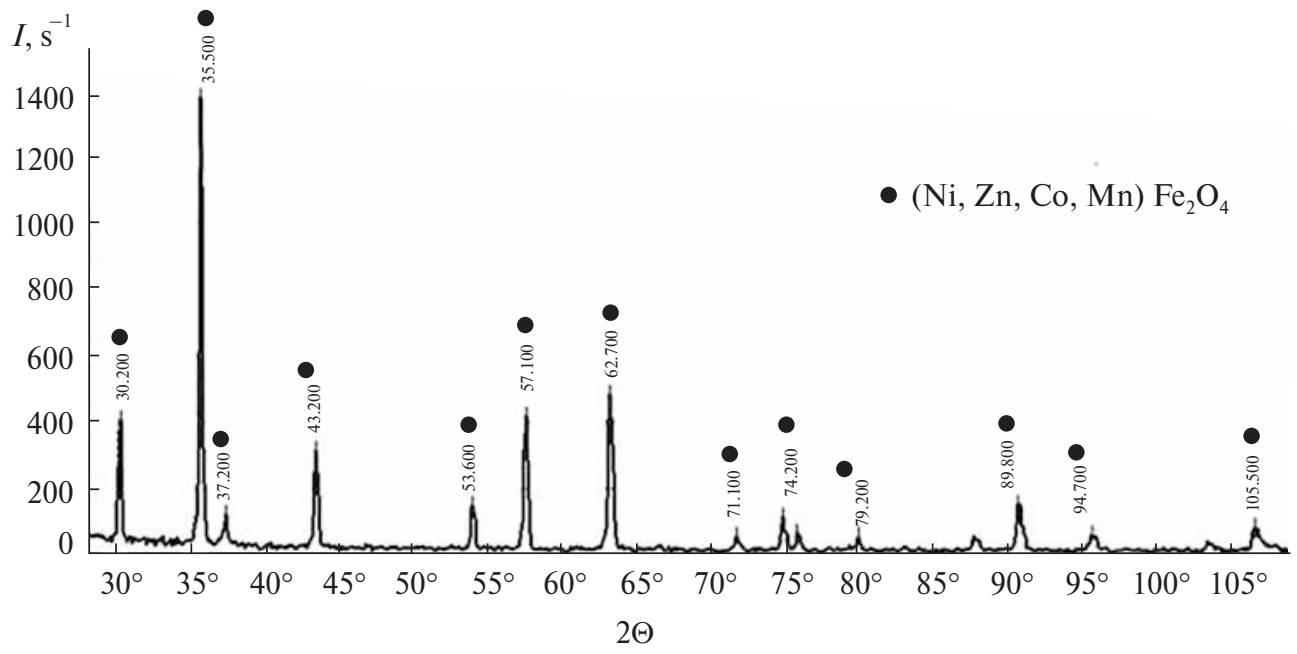

Fig. 2. Phase composition of mechanically activated powder of nickel-zinc ferrite

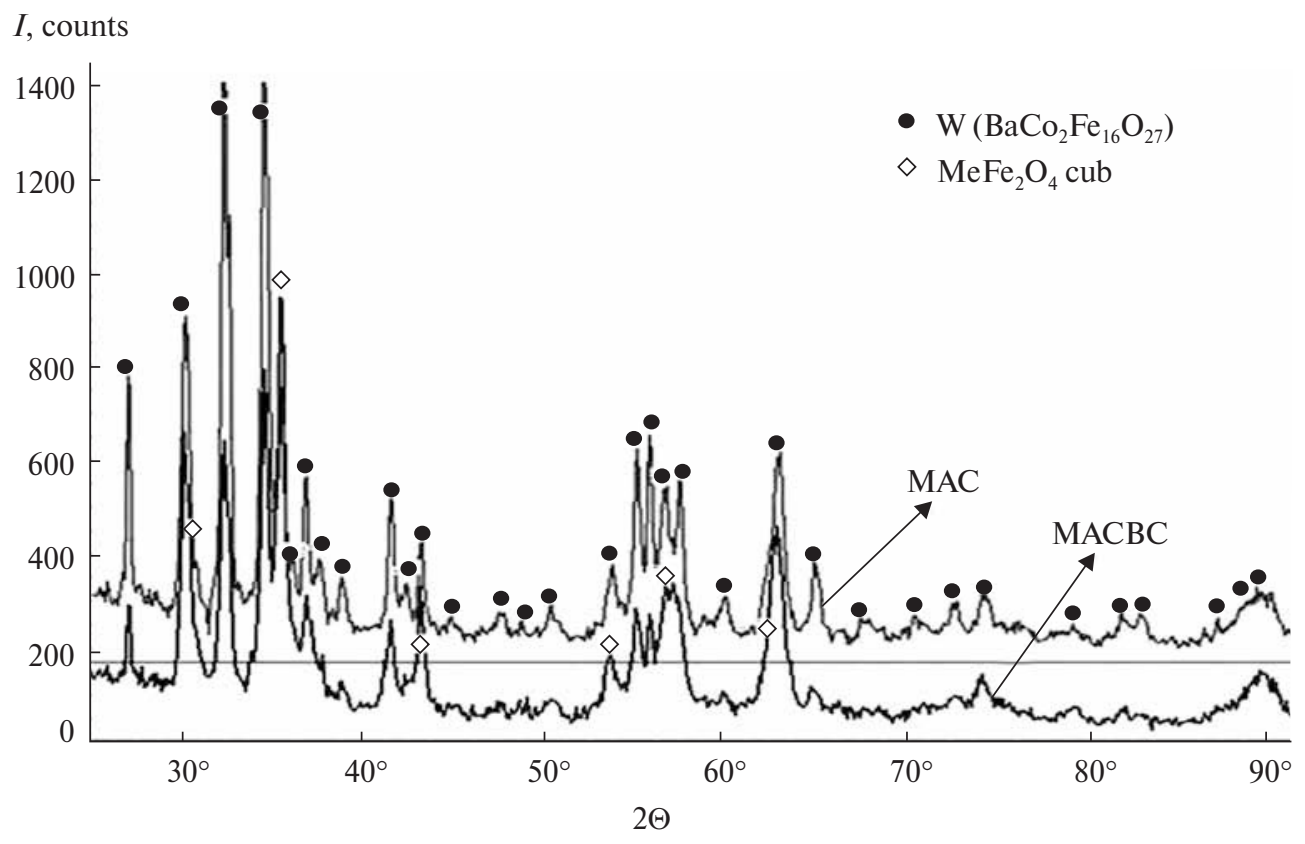

Fig. 3. Phase composition of barium hexaferrite obtained by MAS and MASHS

value in terms of radio absorption of electromagnetic radiation.

The results of the synthesis of barium cobalt hexaferrite by the MAS method depend on the temperature and time of ferritization. During the development of technological modes, it was found that the minimum duration of ferritization with a temperature of $1250 \ldots 1300{ }^{\circ} \mathrm{C}$, at which $70 \ldots 80 \%$ of the
$\mathrm{W}$-phase is formed, is 2 hours. As a rule, $100 \%$ transformation is observed after $4 . .66$ hours of processing and depends on the volumetric load of the furnace. In MASHS synthesis, up to $40 \%$ of the W-phase can be obtained already in the SHS process. In this case, a change in the oxygen pressure in the reactor from 0.5 to $2.0 \mathrm{MPa}$ has no significant effect on the phase composition of SHS products. The maximum con- 

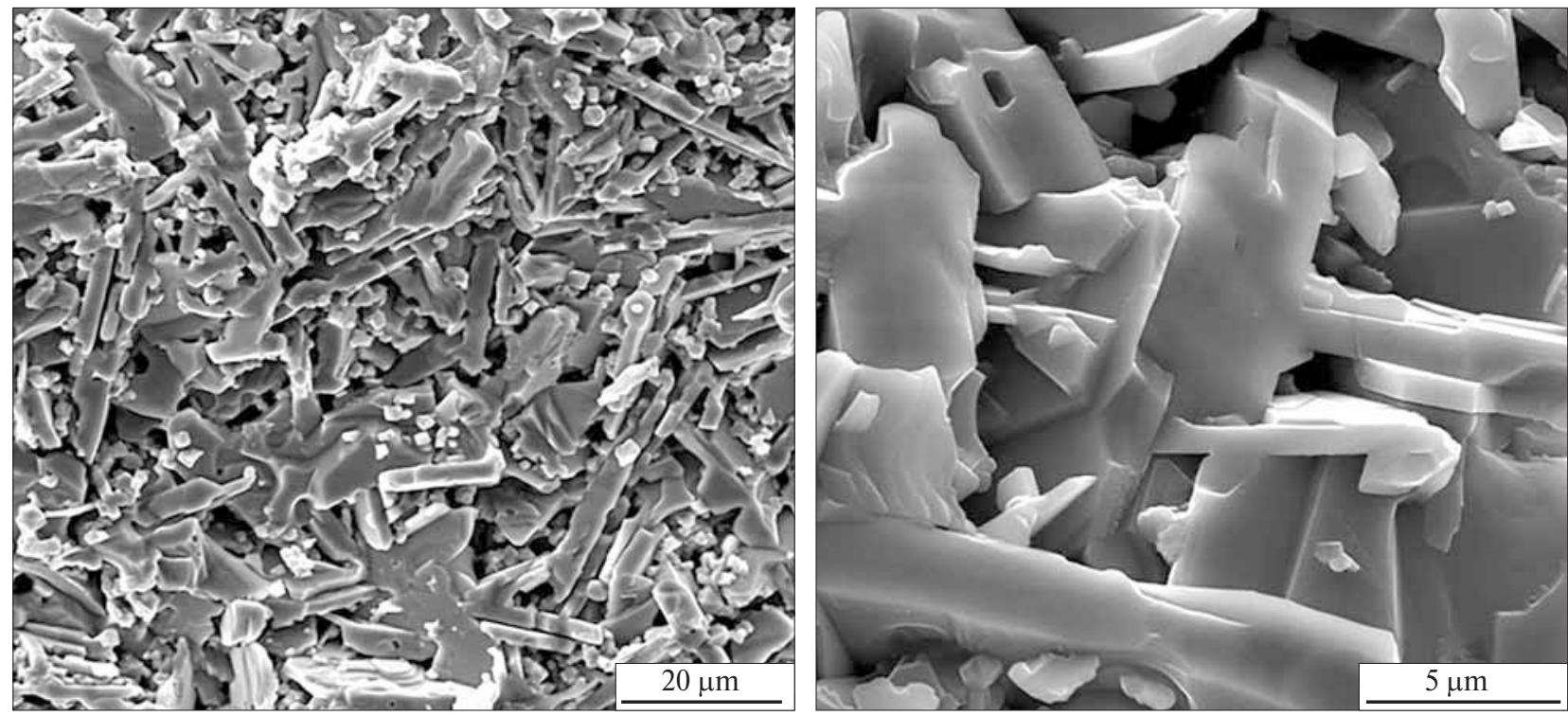

Fig. 4. Surface morphology of $\mathrm{BaCo}_{2} \mathrm{Fe}_{16} \mathrm{O}_{27}$ particles obtained by the MAS method

tent of the W-phase (up to $80 \%$ ) is formed at a Fe: $\mathrm{Fe}_{2} \mathrm{O}_{3}$ ratio of $6: 4$. The results of the analysis of the phase composition of barium hexaferrite obtained by various methods are shown in Fig. 3.

The phase composition of powders obtained using the MASHS scheme with subsequent ferritization practically does not differ from the composition of MAS powders. Taking into account the conclusion made, mechanically activated synthesis, as less laborious, was chosen as the basic method for obtaining barium hexaferrite. The results of the morphological analysis of $\mathrm{BaCo}_{2} \mathrm{Fe}_{16} \mathrm{O}_{27}$ obtained by the MAS method shown in Fig. 4, confirmed the feasibility of choosing this method to obtain it.

When analyzing the morphology of the particles, it was found that the $\mathrm{BaCo}_{2} \mathrm{Fe}_{16} \mathrm{O}_{27}$ powders obtained by the MAS method after ferritization have a platelike shape (Fig. 4) with a crystal faceting characteristic of the W-phase. At high magnifications, the breaks of individual particles show that they have a complex structure with submicron growth steps, which, in turn, have a nanocrystalline structure. Subsequent processing in a planetary mill makes it possible to obtain nanostructured powders or submicron aggregates of ferrite nanoparticles, which significantly improves its radio-absorbing properties.
The developed ferrimagnetic composite materials were tested for functionality by examining the attenuation and reflection coefficients of electromagnetic radiation. The results of the measurements are shown in Fig. 5.

All synthesized materials have shown satisfactory EMP reflection results. Thus, the reflection coefficient for all materials under consideration was less than $-5 \mathrm{~dB}$ in the entire measured frequency band. In this case, the best result (up to $-12 \mathrm{~dB}$ in the frequency band from 8 to $9.5 \mathrm{GHz}$ ) was obtained for the soft magnetic nickel-zinc ferrite obtained by the MASHS method.

The synthesized ferrimagnetic powder materials were considered as fillers in various dielectric matrices, including painting material for casing products, as well as in the form of plates of sintered material and thermal spray coatings on substrates made of aluminum alloys of various components of rocket and space technology.

The synthesis of high-temperature radio-absorbing materials was carried out in accordance with the technological process, the diagram of which is shown in Fig. 6.

For the manufacture of a high-temperature dielectric matrix, aluminum oxide, aluminum nitride, 


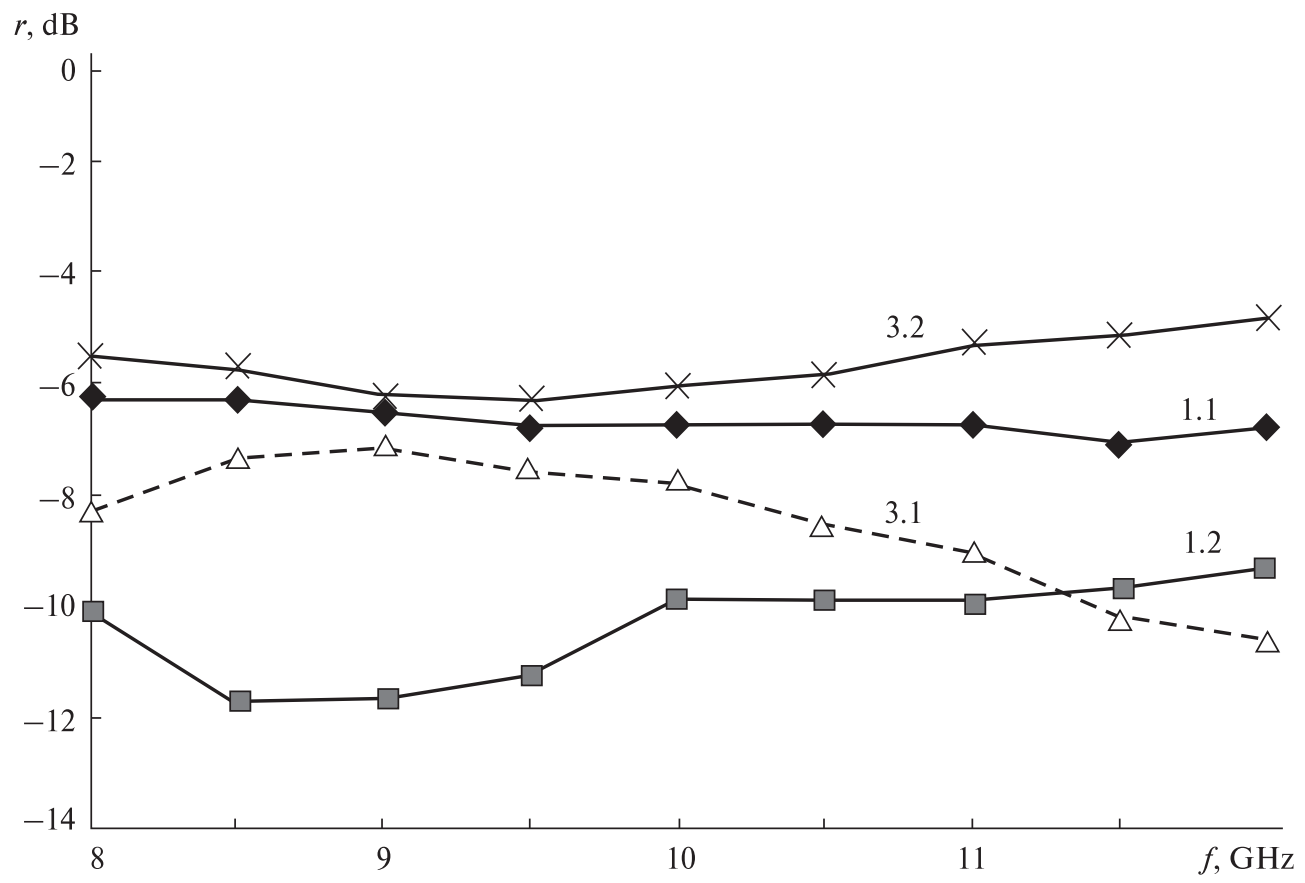

Fig. 5. Reflection coefficient of sintered radio-absorbing materials based on ferrimagnets ( $2 \mathrm{~mm}$ thickness): 1.1 - MAS Ni-Zn ferrite, 1.2 - MASHC Ni-Zn ferrite, 3.1 - MAS barium hexaferrite, 3.2 - MASHC barium hexaferrite

\section{Dielectric matrix}

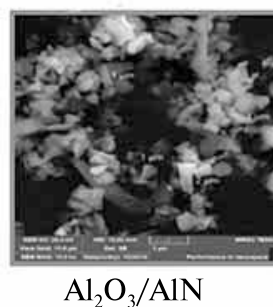

\section{Absorber material}
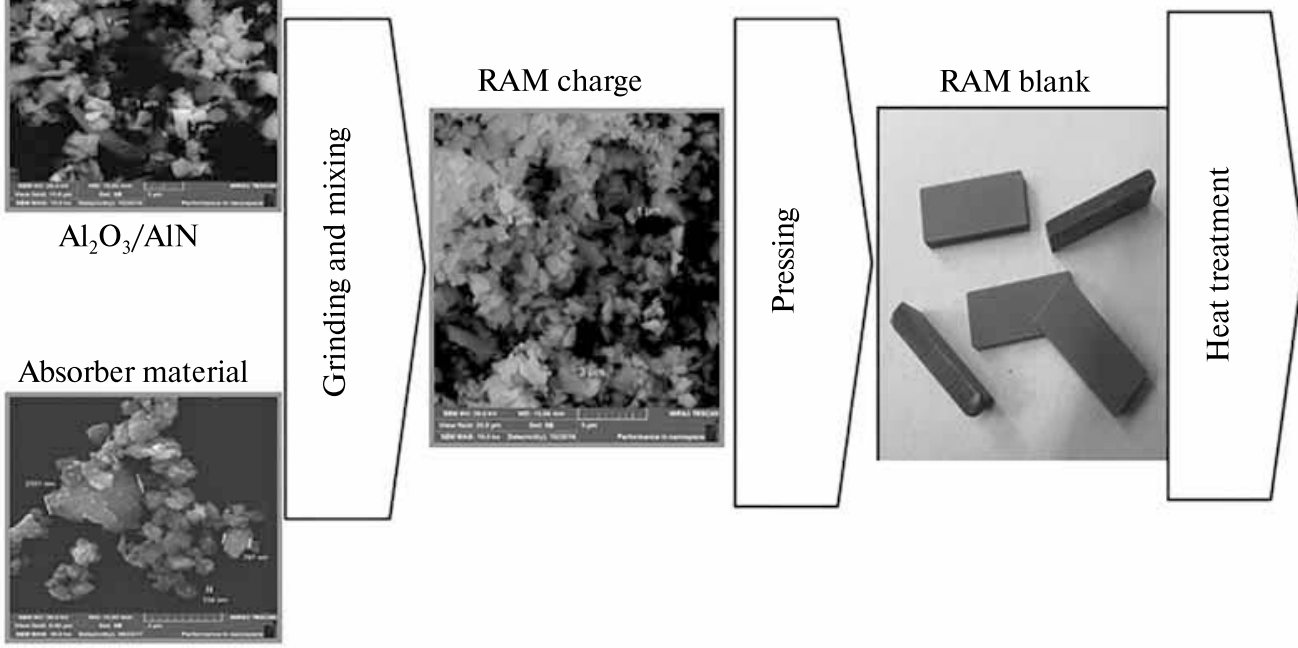

Finished product

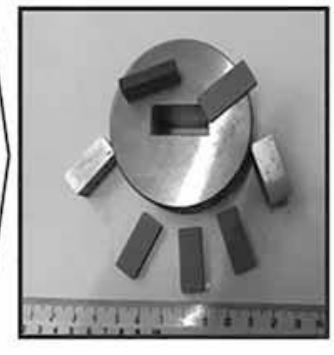

$\mathrm{Ti}_{3} \mathrm{AlC}_{2} / \mathrm{Ti}_{2} \mathrm{Al}$

Fig. 6. Technological process for obtaining high-temperature radio-absorbing material 
or their composition was investigated. A commercial alumina powder was selected as the base matrix material. The choice is justified by the fact that a dielectric material based on aluminum oxide is most suitable for solving problems in terms of dielectric permittivity $(\varepsilon=9.5 \ldots 9.7)$, has a high operating temperature (up to $1400{ }^{\circ} \mathrm{C}$ ) and, as a decisive factor, it can be used to obtain the highest quality thick-film coatings by thermal spraying.

Three groups of conductive materials have been investigated as a high-temperature EMP absorber: resistive materials containing MAX-phases, heat-resistant alloys and intermetallics. All these materials are also characterized by a high operating temperature of over $1200^{\circ} \mathrm{C}$, have electrical conductivity properties, which provides high conductivity losses in the composition of the radar absorbing material. MAX-phases and intermetallic compounds were synthesized by the MASHS method, and heat-resistant alloys were obtained by melt dispersion from a master alloy synthesized using the MAS method from a charge of the corresponding composition.

The results of studying the phase and particle size distribution, morphology of particles, and dielectric properties of synthesized high-temperature radio-absorbing materials in the frequency range $8 \ldots 12 \mathrm{GHz}$ using the example of $\mathrm{Al}_{2} \mathrm{O}_{3}-\mathrm{Ti}_{3} \mathrm{AlC}_{2} / \mathrm{Ti}_{2} \mathrm{AlC}$ composites with MAX-phases as an absorbing filler are shown in Fig. 7.

It was found that in the process of synthesis, composite radio-absorbing materials were created containing from 41.0 to $53.0 \%$ of the dielectric in the form of $\alpha-\mathrm{Al}_{2} \mathrm{O}_{3}$ and from 39 to $56 \%$ of the conductive absorber, which ultimately makes it possible to provide dielectric losses, conductivity losses, and in heat-resistant alloys - and magnetic losses in the frequency range $8 \ldots 12 \mathrm{GHz}$.

All synthesized powder radio-absorbing materials are finely dispersed $(\mathrm{d} 50=0.14 \ldots 1.2 \mu \mathrm{m})$ with a rounded shape of particles formed in the processes of intensive grinding and mixing, which contributes to their thermal spraying when obtaining RAC.

When studying the electromagnetic properties of the synthesized high-temperature radio-absorbing materials, it was found that with an increase in the content of the absorber in the dielectric matrix, the values of both the real and imaginary parts of the di- electric constant increase. The tangent of the dielectric loss angle increases. For the $\mathrm{Al}_{2} \mathrm{O}_{3}$ /heat-resistant alloy composition, the values of the magnetic permeability and the tangent of the angle of magnetic losses also increase.

According to the results of the study, the optimal content of the high-temperature conductive absorber in the dielectric ceramic matrix in the amount of $40 . .50$ wt. $\%$ has been established.

In Fig. 7, from $e$ and $f$ it also follows that the dependence of dielectric properties on the test frequency is wavy in nature. For the $\mathrm{Al}_{2} \mathrm{O}_{3}-\mathrm{Ti}_{3} \mathrm{AlC}_{2} /$ $\mathrm{Ti}_{2} \mathrm{AlC}$ composition, the values of the real part of the dielectric constant are in the range $\varepsilon^{\prime}=17 \ldots 28$, and the imaginary part - in the range $\varepsilon^{\prime \prime}=5 \ldots 12$, which is optimal and provides the tangent of the dielectric loss angle $\operatorname{tg} \delta_{\varepsilon}=0.25 \ldots 0.58$ with a maximum value at a frequency of $f=10.3 \mathrm{GHz}$. For doped ceramic $\mathrm{RAM} \mathrm{Al}_{2} \mathrm{O}_{3}+\mathrm{FeSiTiAl}$, the best values of $\operatorname{tg} \delta_{\varepsilon}=0.30 \ldots 0.38, \operatorname{tg} \delta_{\varepsilon}=0.78 \ldots 0.82, \mathrm{~S}_{11}=-2.2 \ldots$ $-2.5 \mathrm{~dB}, \mathrm{~S}_{22}=10.0 \ldots 10.2 \mathrm{~dB}$ are achieved.

Along with radio-absorbing materials and products (coatings), the Powder Metallurgy Institute is conducting research on the creation of radio-transparent materials.

When developing radio-transparent materials, the process of preparing compositions based on highalumina ceramics was studied using high-purity fused corundum powder as a starting material, as well as alloying additives in the form of oxides of silicon, magnesium, titanium, etc., activating the sintering process in order to obtain the required set of properties. The influence of the modes of preparation of the initial materials for obtaining a homogeneous finely dispersed charge is established, the modes of its granulation, subsequent static pressing and high-temperature sintering are determined in order to obtain the required physical-mechanical, thermomechanical and electrophysical properties. The structure, phase composition and properties of the obtained radiotransparent materials have been investigated and their dependence on the composition and modes of the technological process is shown.

Based on the research results, a ceramic radiotransparent material based on high-alumina ceramics has been developed, the main properties of which are shown in the Table. 

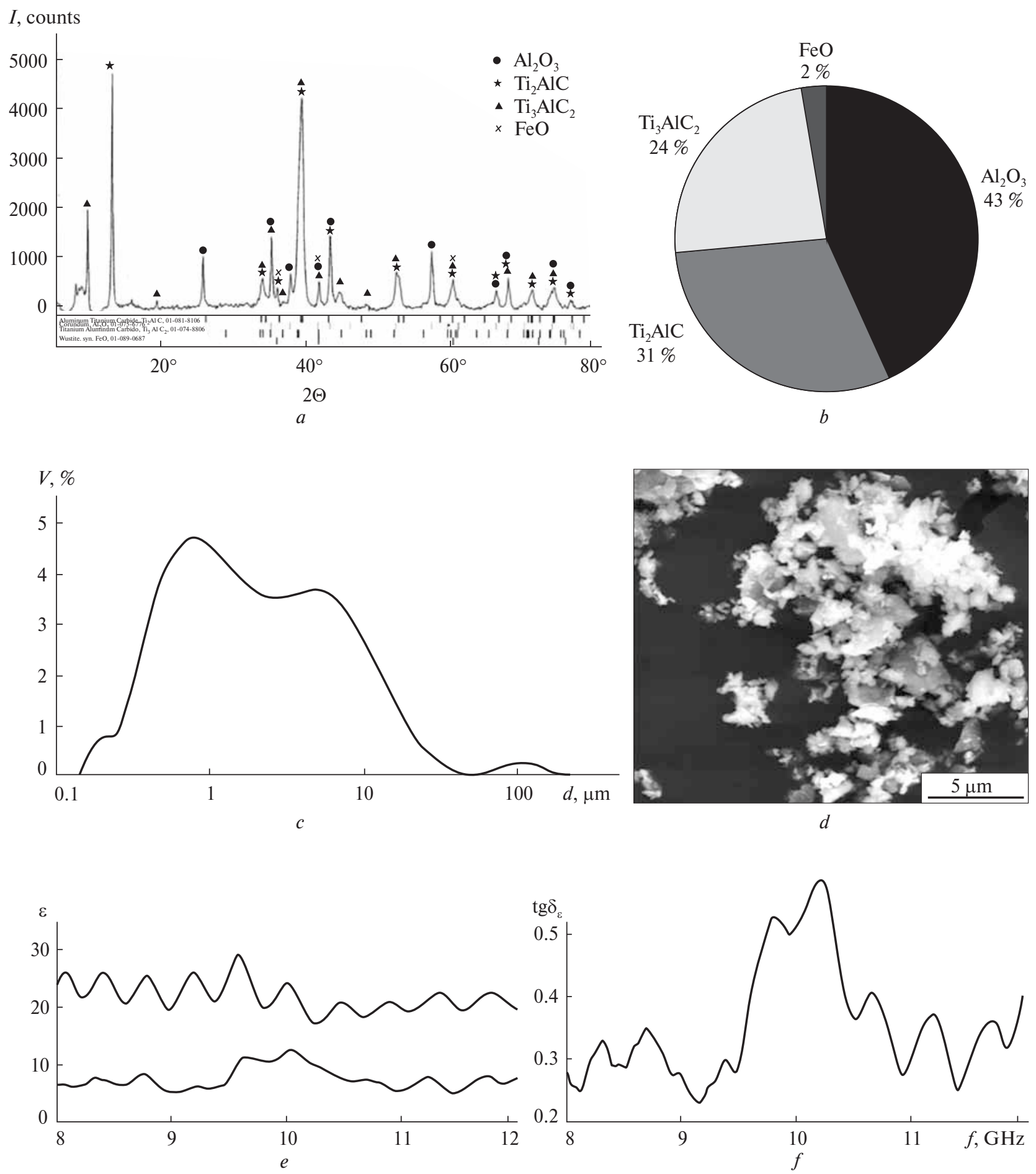

Fig. 7. Properties of powder radio-absorbing material of the $\mathrm{Al}_{2} \mathrm{O}_{3}-\mathrm{Ti}_{3} \mathrm{AlC}_{2} / \mathrm{Ti}_{2} \mathrm{AlC}$ system in the frequency range $8 \ldots 12 \mathrm{GHz}$ : $a, b$ - phase composition, $c$ - particle size distribution, $d$ - particle morphology, $e$ - real and imaginary parts of the dielectric constant, $f$ - dielectric loss tangent 
Properties of the synthesized radio-transparent material based on high-alumina ceramics

\begin{tabular}{|l|c|}
\hline \multicolumn{1}{|c|}{ Measured characteristics } & Value \\
\hline Operating frequency range, $\mathrm{GHz}$ & $6.5 \ldots 10.5$ \\
Dielectric constant at $f=7 \mathrm{GHz}$ & $6 \ldots 8$ \\
Dielectric loss tangent $\operatorname{tg} \delta_{\varepsilon}$ & $\leq 0.0007$ \\
Deviation $\varepsilon$ in the range of impacts, $\%$ & \pm 2.8 \\
EMP absorption, $\%$ & $\leq 2.0$ \\
Apparent density, g/cm ${ }^{3}$ & $\leq 2.7$ \\
Limit strength to bending, MPa & $\geq 50$ \\
Water absorption, $\%$ & $\leq 0.1$ \\
Modulus of elasticity to bending, GPa & $\geq 30$ \\
Heat resistance, K & 850 \\
\hline
\end{tabular}

The electrophysical characteristics of the synthesized composition correspond to the requirements for radio-transparent materials presented by the customer.

\section{CONCLUSIONS}

Powder metallurgy is a technology for creating unique composite materials from dispersed components of different physical and chemical nature throughout its development is inextricably linked with rocket and space technology. The use of powder materials in the design of engines, control and guidance units has greatly contributed to the progress of space technology.

In modern conditions, it is difficult to imagine a rocket engine without inserts into the critical section made of a carbon-carbon composite material, a head fairing without a top made of a heavy pseudo-alloy or radio-transparent material, friction pairs in moving elements without antifriction self-lubricating materials and coatings, etc.

A promising area of powder metallurgy is radioabsorbing composite materials in the frequency range of $8 \ldots 12 \mathrm{GHz}$, especially those that do not lose this ability at temperatures of $1000{ }^{\circ} \mathrm{C}$ and above. Such materials have already been synthesized at the Powder Metallurgy Institute and are undergoing field tests.

A fairly new direction in powder metallurgy has become the production of unique one-piece structures of rocket and space technology units of any complexity, previously assembled from a group of parts. The additive metallurgical technologies developed for these purposes use special spherical powders of high-strength heat-resistant alloys such as Inconel 625,718 , titanium alloys Ti6Al4V, etc.

In the future, additive technologies in conjunction with traditional methods of powder metallurgy can be transformed into the field of knowledge that determines the approaches and methods for the synthesis of energy-saturated heterogeneous composite materials $(E H C M)$ and the manufacture of products from them. The possibility of this realization will depend on the solution of the following tasks:

- development of technologies for obtaining spherical particles of ammonium salt of perchloric acid and other components of the solid phase of EHCM (energy additives, catalysts, combustion stabilizers, etc.);

- synthesis of a polymer that performs the function of a fuel - binding and guaranteeing the physical and mechanical characteristics required for such products;

- determination of the environment in which it is possible to build a product from EHCM, as well as methods of its creation;

- development of technological equipment to ensure the laying of EHCM components;

- determination of the method of packing the solid phase particles of EHCM with a density not lower than $0.84 \ldots . .8$;

- development of a method for forming the required shape of a product from EHCM;

- carrying out calculations of contact interactions arising in the process of stacking solid phase particles;

- study of the processes occurring at the phase boundary during the synthesis of EHCM;

- development of a model for the synthesis of EHCM and the manufacture of a product from it by the method of additive technologies, etc.

The solution of the above tasks will work out the requirements and build a functional model of a technical system, through which it is possible to build products from EHCM according to a given program. In turn, the development of this method of constructing products from EHCM will significantly enrich the theory of powder metallurgy and make it even more significant in the development of components for rocket and space technology. 


\section{REFERENCES}

1. Il'yushchenko A. F., Baraj S. G., Nasonova N. V. (2014). Scientific approaches to the creation of radio absorbing microwave materials for operation at elevated temperatures. Minsk: Belaruskaya navuka [in Russian].

2. Il'yushchenko A. F, Baraj S. G., Talako T. L., Lecko A. I., Nasonova N. V. (2017). Synthesis and research of radio absorbing materials based on ferrimagnetic materials. Minsk: Belaruskaya navuka [in Russian].

3. Kiparisov S. S., Libenson G. A. (1980). Powder Metallurgy. Moscow: Nauka [in Russian].

4. Kovneristyj Yu. K., Lazareva I. Yu, Ravaev A. A. (1982). Materials absorbing microwave radiation. Moscow: Nauka [in Russian].

5. Radio absorbing and radio transparent materials. URL: http://www.xumuk.ru/encyklopedia/2/3801.html (Last accessed: 10.10.2019).

6. Suzdal'cev E. I. (2014). Ceramic radio-transparent materials: yesterday, today and tomorrow. URL: https://doi.org/10.17073/ 1683-4518-2014-10-5-18 (Last accessed: 10.10.2019).

Received on 10.10.2019

О. Ф. Ільющенко ${ }^{1,2}$, Генеральний директор ДНВО порошкової металургії -

директор ДНУ «Інститут порошкової металургії імені академіка О. В. Романа»,

д-р техн. наук, проф., чл.-кор. НАН Білорусії

E-mail: Alexil@mail.belpak.by

O. К. Кривонос ${ }^{1}$, Заст. генерального директора, канд. військ. наук

E-mail: Krivonos_ok@tut.by

С. Г. Барай ${ }^{2}$, зав. лаб. кераміки, канд. техн. наук

B. B. Савич ${ }^{2}$, Перший заст. директора - заст. директора з науки, канд. техн. наук, доцент

E-mail: savich@pminstitute.by

${ }^{1}$ Державне науково-виробниче об'єднання порошкової металургії

вул. Платонова 41, Мінськ, Білорусь, 220005

2 Державна наукова установа «Інститут порошкової металургії імені академіка О. В. Романа» вул. Платонова 41, Мінськ, Білорусь, 220005

\section{МАТЕРІАЛИ І ТЕХНОЛОГІЇ ПОРОШКОВОЇ МЕТАЛУРГІЇ В КОМПОНЕНТАХ РАКЕТНО-КОСМІЧНОЇ ТЕХНІКИ. ПЕРСПЕКТИВИ РОЗВИТКУ}

Розглянуто використання матеріалів і технологій порошкової металургії в компонентах ракетно-космічної техніки. На прикладі радіопоглинальних і радіопрозорих матеріалів показано можливості цих технологій для створення композиційних матеріалів, а також виробів і покриттів з них.

Розроблено способи синтезу радіопоглинальних матеріалів на основі феримагнетиків (нікель-цинкових феритів $\left(\mathrm{Ni}_{0.58} \mathrm{Zn0}_{0.36} \mathrm{Mn}_{0.06} \mathrm{Co}_{0.028} \mathrm{Fe}_{2} \mathrm{O}_{4}\right)$ і гексагонального фериту барію з $\mathrm{W}$-фазою $\left(\mathrm{BaCo}_{2} \mathrm{Fe}_{16} \mathrm{O}_{27}\right)$, отриманих методами МАС і МАСВС. Досліджено способи отримання високотемпературних керамічних радіопоглинальних матеріалів, що використовують оксид алюмінію як діелектричну матрицю, а як поглинач електромагнітного імпульсу - резистивний матеріал, що містить MAX-фази $\mathrm{Ti}_{2} \mathrm{AlC} \mathrm{i} \mathrm{Ti}_{3} \mathrm{AlC}_{2}$, і жаростійкий сплав FeSiTiAl.

Запропоновано спосіб отримання керамічного композиційного радіопрозорого матеріалу на основі високоглиноземистої кераміки в системі $\mathrm{Al}_{2} \mathrm{O}_{3}-\mathrm{SiO}_{2}-\mathrm{TiO}_{2}$. Наведено характерні технологічні особливості методу порошкової металургії, що забезпечують отримання матеріалів і виробів (покриттів) для ракетно-космічної техніки з необхідними властивостями.

Визначено основні завдання для порошкової металургії в області отримання енергонасичених гетерогенних композиційних матеріалів.

Ключові слова: порошкова металургія, ракетно-космічна техніка, радіопоглинальні і радіопрозорі матеріали, феримагнетики, високоглиноземиста кераміка. 